\title{
ANALISIS KEPUASAN PENGGUNA APLIKASI OJEK ONLINE MENGGUNAKAN METODE TECHNOLOGY ACCEPTANCE MODEL (TAM)
}

\author{
${ }^{1}$ Novian Putra Utama, ${ }^{2}$ Fintri Indriani \\ 1Program Studi Sistem Informasi \\ STMIK Nusa Mandiri Jakarta \\ www.nusamandiri.ac.id \\ novianputraid@gmail.com \\ 2Program Studi Sistem Informasi Akuntansi \\ Universitas Bina Sarana Informatika \\ www.bsi.ac.id/ubsi \\ fintri.fni@bsi.ac.id
}

\begin{abstract}
Congestion in Jakarta is a phenomenon that has become a scourge of the community, congestion occurs because of the increasing number of motorized vehicles in Jakarta, the lack of public awareness of driving and traffic and the lack of public awareness of the use of public transportation which is one of the solutions to reduce congestion in Jakarta. Based on the description on the background of the problem, it can be identified several problems, including 1) Does ease of perception (Percived Ease of Use) have a positive effect on the acceptance of the online motorcycle taxi application system in Indonesia? 2) Does the perceived usefulness (Percived Usefulness) have a positive effect on the acceptance of online motorcycle taxi applications in Indonesia? The purpose of this study is to analyze and test whether ease of perception (Percived Ease of Use) has a positive effect on the acceptance of online motorcycle taxi application systems in Indonesia, and to analyze and test whether the benefits of perceived use (Percived Usefulness) have a positive effect on the acceptance of online motorcycle taxi applications in Indonesia.
\end{abstract}

Keywords: User Satisfaction, Online Motorcycle taxi Application, TAM

Abstrak-Kemacetan di Jakarta adalah suatu fenomena yang sudah menjadi momok masyarakat, kemacetan terjadi karena semakin banyaknya kendaraan bermotor yang ada di Jakarta, masih kurangnya kesadaran masyarakat berkendaraan dan berlalu lintas dan kurang nya tingkat kesadaran masyarakat akan penggunaan transportasi umum yang menjadi salah satu solusi untuk mengurangi kemacetan di Jakarta. Berdasarkan uraian pada latar belakang masalah, maka dapat di idetifikasikan beberapa masalah, diantaranya 1) Apakah kemudahan persepsian (Percived Ease Of Use) berpengaruh positif terhadap penerimaan sistem aplikasi ojek online di Indonesia? 2) Apakah kemanfaatan persepsian (Percived Usefulness) berpengaruh positif terhadap penerimaan aplikasi ojek online di Indonesia?. Tujuan penelitian ini untuk menganalisis dan menguji apakah kemudahan persepsian (Percived Ease Of Use) berpengaruh positif terhadap penerimaan sistem aplikasi ojek online di Indonesia, dan untuk menganalisis dan menguji apakah kemanfaatan persepsian (Percived Usefulness) berpengaruh positif terhadap penerimaan aplikasi ojek online di Indonesia.

Kata Kunci: Kepuasan Pengguna, Aplikasi Ojek Online, TAM

\section{PENDAHULUAN}

Ojek online saat ini adalah suatu fenomena yang patut kita perhatikan, seperti yang kita ketahui sekarang terdapat tiga raksasa penyedia layanan ojek berbasis online yaitu, Go-Jek, Grabbike, dan UberMotor. Mereka bersaing dalam menarik minat masyarakat untuk menggunakan layanan yang mereka sediakan diantaranya dengan meningkatkan software aplikasi untuk semakin mudah di gunakan oleh masyarakat dari berbagai kalangan seperti anak-anak, orang dewasa hingga lansia. Kemacetan di Jakarta adalah suatu fenomena yang sudah menjadi momok masyarakat (Fahmi, Umyati, Riyanto, \& Basuki, 2015), kemacetan terjadi karena semakin banyaknya 
kendaraan bermotor (Sengkey, Jansen, \& Wallah, 2011) yang ada di Jakarta, masih kurangnya kesadaran masyarakat berkendaraan dan berlalu lintas (Soesilowati, 2008) dan kurang nya tingkat kesadaran masyarakat akan penggunaan transportasi umum yang menjadi salah satu solusi untuk mengurangi kemacetan di Jakarta.

Tingkat kepadatan lalu lintas di DKI Jakarta terus meningkat. Hal ini telah menyebabkan tingkat kemacetan semakin tinggi, yang menimbulkan kerugian di masyarakat (Soebali \& Mahendra, 2017). Menurut Arie Setiadi Moerwanto, Kepala Badan Penelitian dan Pengembangan Kementerian Pekerjaan Umum dan Perumahan Rakyat, kerugian yang diakibat kemacetan di Jakarta mencapai Rp. 65 triliun per tahun (Rachman, 2015). Dinas Perhubungan DKI Jakarta mencatat kerugian masyarakat dari dampak kemacetan di sejumlah wilayah Jakarta mencapai Rp 150 triliun per tahun. (Zuraya, 2016).

Berdasarkan uraian pada latar belakang masalah, maka dapat di idetifikasikan beberapa masalah, diantaranya 1) Apakah kemudahan persepsian (Percived Ease of Use) berpengaruh positif terhadap penerimaan sistem aplikasi ojek online di Indonesia? 2) Apakah kemanfaatan persepsian (Percived Usefulness) berpengaruh positif terhadap penerimaan aplikasi ojek online di Indonesia?

Mengacu pada identifikasi masalah yang di uraikan di atas, maka di dapatkan beberapa hipotesis dalam penelitian ini

$\mathrm{H}_{1}$ : Terdapat persepsi terhadap kemudahan penggunaan (Perceived Ease Of Use).

$\mathrm{H}_{2}$ : Terdapat persepsi terhadap manfaat penggunaan (Perceived Usefulness).

Adapun penelitian ini dilakukan untuk mengetahui seberapa besar pengaruh persepsi pemanfaatan dan kemudahan terhadap aplikasi ojek online. Penelitian ini mengadopsi model technology acceptance model (TAM) dalam upaya pengembangan model penelitiannya. Tujuan penelitian ini untuk menganalisis dan menguji apakah kemudahan persepsian (Percived Ease of Use) berpengaruh positif terhadap penerimaan sistem aplikasi ojek online di Indonesia, dan untuk menganalisis dan menguji apakah kemanfaatan persepsian (Percived Usefulness) berpengaruh positif terhadap penerimaan aplikasi ojek online di Indonesia?

\section{METODE PENELITIAN}

Dalam penyusunan penelitian dengan mengambil objek penelitian pengguna jasa ojek online yang saat ini telah mencapai 10 juta unduhan untuk Go-jek, 10 juta unduhan untuk Grabbike, dan 10 juta unduhan untuk UberBike (sumber : Playstore, 2017).

\section{A. Tahapan Penelitian}

Dalam penelitian ini ditujukan untuk menganalisa dan mendeskripsikan tentang datadata tingkat kepuasan pengguna aplikasi ojek online dengan metode Technology Acceptance Model (TAM). Penelitian ini adalah penelitian survei yang dilakukan dengan kuesioner sebagai pengumpul data-data yang diperlukan. Berikut ini adalah kerangka pemikiran yang telah di rancang untuk melakukan penelitian yang sedang dikaji.

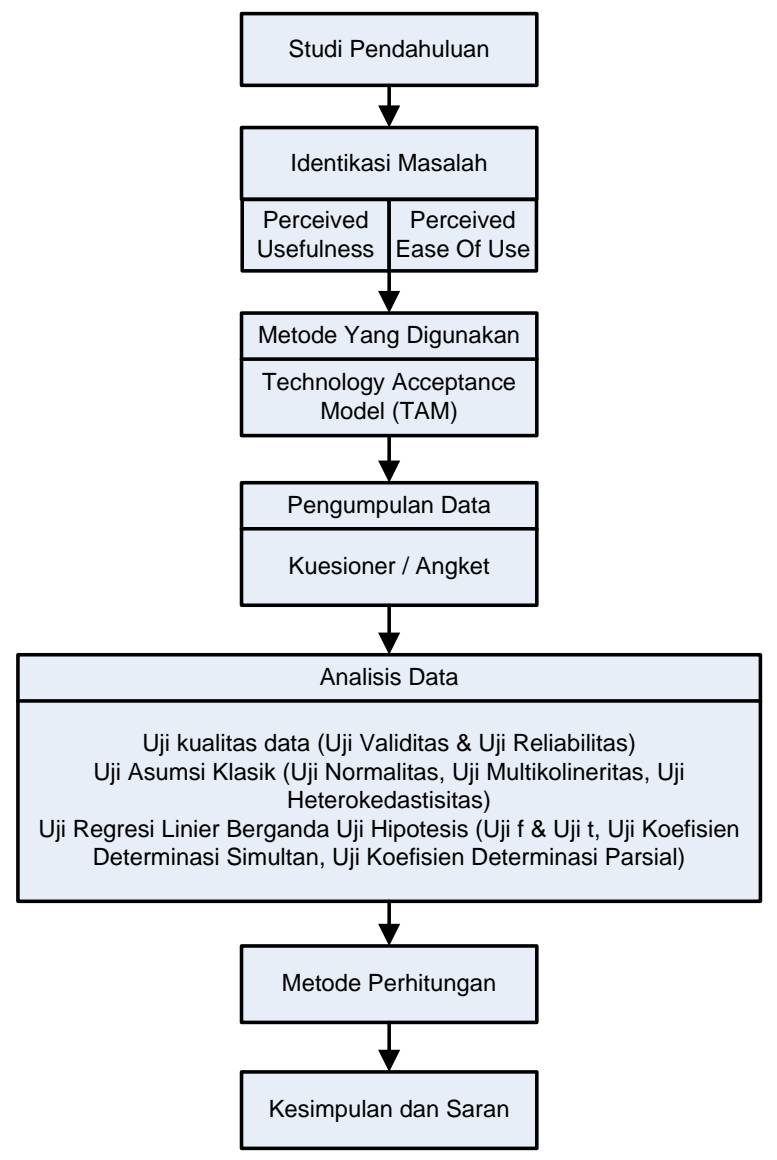

Gambar 1. Struktur Penelitian

\section{B. Intrumen Penelitian}

Alat yang digunakan berupa kuesioner yang memuat sejumlah pertanyaan tertulis dari responden. Instrumen yang digunakan dalam penelitian ini menggunakan kuesioner yang sebagai alat pengumpul data-data yang diperlukan. Dan untuk variabel penelitan menggunakan variabel :

1. Kemudahan (Ease Of Use) Variabel ini dibuat untuk mengukur sejauh mana pengguna percaya bahwa Aplikasi ojek online mudah untuk digunakan. 
Tabel 1. Item-item Konstruk Kemudahan Persepsian

\begin{tabular}{lll}
\hline Dimensi & No. & Indikator \\
\hline Kemudahan & 1. & Mudah dipelajari \\
\cline { 2 - 3 } Persepsian & 2. & Dapat dikontrol \\
\cline { 2 - 3 } & 3. & Jelas \& dapat dipahami \\
\cline { 2 - 3 } & 4. & Fleksibel \\
\hline 5. & $\begin{array}{l}\text { Mudah untuk menjadi } \\
\text { terampil/mahir }\end{array}$ \\
& & Mudah digunakan \\
\hline
\end{tabular}

2. Kegunaan (Usefulness) Variabel ini dibuat untuk mengukur sejauh mana pengguna percaya bahwa menggunakan Aplikasi ojek online akan meningkatkan kinerja.

Tabel 2. Item-item Konstruk Kemanfaatan Persepsian

\begin{tabular}{lll}
\hline Dimensi & No. & Indikator \\
\hline Kemanfaatan & 1. & Mempercepat pekerjaan \\
\cline { 2 - 3 } Persepsian & 2. & Meningkatkan kinerja \\
\cline { 2 - 3 } & 3. & $\begin{array}{l}\text { Meningkatkan } \\
\text { produktivitas }\end{array}$ \\
\cline { 2 - 3 } & 4. & Efektifitas \\
\cline { 2 - 3 } & 5. & Mempermudah pekerjaan \\
\hline & 6. & Bermanfaat \\
\hline
\end{tabular}

3. Penerimaan Sistem Variabel ini merupakan konstruk endogen untuk mengetahui pengaruh antara konstruk Kemudahan penggunaan persepsian dan konstruk Kemanfaatan persepsian terhadap penerimaan sistem Aplikasi Ojek Online.

Tabel 3. Item-item Konstruk Penerimaan Sistem

\begin{tabular}{lll}
\hline Dimensi & No. & Indikator \\
\hline $\begin{array}{l}\text { Penerimaan } \\
\text { Sistem }\end{array}$ & 1. & $\begin{array}{l}\text { Pengguna selalu } \\
\text { menggunakan }\end{array}$ \\
\hline & 2. & Selalu mengakses \\
\hline & 3. & Kepuasan pengguna \\
\hline
\end{tabular}

Kuesioner suatu teknik pengumpulan data dengan mengajukan beberapa pernyataan secara tertulis dan diberikan langsung kepada responden (Sugiyono, 2010). Dalam penelitian ini kuesioner yang digunakan berbentuk skala likert. Kuesioner dilakukan dengan membagikan 100 responden yang menggunakan jasa aplikasi ojek online. Data yang diperoleh dari kuesioner ini akan diolah dengan perhitungan persentase, yaitu melihat berapa persentase responden dengan skor sebagai berikut:

$\begin{array}{ll}\text { Sangat Setuju } & (\mathrm{SS})=5 \\ \text { Setuju } & \text { (S) }=4\end{array}$

$\begin{array}{lll}\text { Netral } & (\mathrm{N}) & =3 \\ \text { Tidak Setuju } & \text { (TS) } & =2 \\ \text { Sangat Tidak Setuju } & \text { (STS) } & =1\end{array}$

\section{Metode Pengumpulan Data, Populasi dan Sample Penelitian}

\section{Metode Pengumpulan Data}

Dalam penelitian ini, metode pengumpulan data menggunakan riset lapangan. Riset lapangan digunakan untuk mengumpulkan data dari responden. Pengumpulan data dilapangan dilakukan dengan menggunakan kuesioner yang diberikan kepada responden secara langsung.

\section{Populasi dan Sample penelitian}

1. Populasi

Populasi dalam penelitian ini adalah seseorang yang di ambil secara acak untuk di jadikan sampel penelitian atau seseorang yang sudah dikenal oleh penulis yang kemudian di jadikan sampel dalam penelitian ini. Populasi dalam penelitian ini sebanyak 10.000 .000 orang mengunduh aplikasi ojek online dan diperoleh dari Play Store 2017.

\section{Sample penelitian}

Dalam penelitian ini teknik sampling yang digunakan adalahteknik simple random sampling karena sampel diambil secara acak tanpa memperhatikan strata yang ada dalam populasi tersebut.Untuk menentukan jumlah besaran sampel penulis menggunakan rumus slovin dengan batas toleransi kesalahan sebesar 10\%. Berikut adalah rumus sampel yang akan dipakai :

$n=\frac{N}{1+N e^{2}}$

Dimana:

$\mathrm{n}$ = Ukuran sampel; $\mathrm{N}=$ Ukuran populasi; $\mathrm{e}=$ Batas toleransi kesalahan

$$
\begin{aligned}
& n=\frac{10.000 .000}{1+10.000 .000(0,10)^{2}} \\
& n=\frac{10.000 .000}{100.001} \\
& n=99,9=100
\end{aligned}
$$

Jumlah sampel yang dibutuhkan dari hasil perhitungan menggunakan rumus slovin adalah sebesar 99,9 yang kemudian dibulatkan menjadi 100. 


\section{Metode Analisis Data}

Metode analisis data yang digunakan dalam penelitian ini menggunakan analisis persamaan regresi linier ganda, uji asumsi klasik (normalitas, multikolinearitas, dan heterokedastisitas), koefisien determinasi, uji F, dan uji t.

\section{HASIL PENELITIAN DAN PEMBAHASAN}

\section{A. Gambaran Umum Responden}

Penelitian ini akan menjelaskan tentang hubungan antara variabel kemanfaatan persepsian dan kemudahan persepsian terhadap penerimaan sistem pada aplikasi ojek online di Indonesia. Populasi pada penelitian ini adalah masyarakat DKI Jakarta yang menggunakan aplikasi ojek online. Sampel yang diambil pada penelitian ini adalah 100 orang. Di dalam penelitian ini, akan dilihat karakteristiknya melalui jenis kelamin, usia dan pekerjaan. Hal ini agar dapat mengetahui gambaran secara umum pada pengguna aplikasi ojek online.

1. Profil Responden Berdasarkan Jenis Kelamin

\begin{tabular}{lcc}
\multicolumn{3}{c}{ Tabel 4. Jenis kelamin } \\
\hline Jenis Kelamin & Frekuensi & Persentase (\%) \\
\hline Laki-laki & 36 & $36 \%$ \\
\hline Perempuan & 64 & $64 \%$ \\
\hline TOTAL & 100 & $100 \%$ \\
\hline
\end{tabular}

Tabel 4 menjelaskan bahwa dari 100 responden yang ada responden yang paling banyak menggunakan aplikasi ojek online pada kota DKI Jakarta adalah responden yang berjenis kelamin perempuan yaitu sebesar $64 \%$ atau berjumlah 64 responden, sedangkan responden laki-laki sebesar 36\% yang berjumlah 36 responden. Dari informasi tersebut, maka dapat disimpulkan bahwa rata-rata yang menjadi responden pengguna aplikasi ojek online adalah perempuan daripada responden laki-laki.

\section{Profil Responden Berdasarkan Usia}

Tabel 5. Usia

\begin{tabular}{lrc}
\hline \multicolumn{1}{c}{ Usia } & Frekuensi & $\begin{array}{c}\text { Persentase } \\
(\%)\end{array}$ \\
\hline $17-20$ Tahun & 31 & $31 \%$ \\
\hline $21-30$ Tahun & 48 & $48 \%$ \\
\hline$\geq 30$ Tahun & 21 & $21 \%$ \\
\hline Total & 100 & $100 \%$ \\
\hline
\end{tabular}

Dari tabel 5, dapat dijelaskan bahwa responden yang paling banyak menggunakan aplikasi ojek online dalam penelitian ini adalah mereka yang berusia antara 21 - 30 tahun dengan persentase $48 \%$ atau sebanyak 48 responden, responden berusia 17 - 20 tahun dengan persentase $31 \%$ atau sebanyak 31 responden dan yang lainnya adalah responden dengan berusia lebih dari atau sama dengan 30 tahun dengan persentase $21 \%$ atau sebanyak 21 responden. Dapat disimpulkan bahwa rata-rata yang menjadi responden penelitian adalah responden yang berusia antara 21 - 30 tahun yaitu sebanyak 48 responden. Hal ini dikarenakan menurut Fredereca dan Chairy mengatakan usia 21 - 30 tahun di katakan mampu mengenali suatu kebutuhan barang atau jasa, serta mampu mengambil keputusan untuk memilih suatu produk/jasa dan dapat memahami mengenai informasi yang di sajikan .

\section{Profil Responden Berdasarkan Pekerjaan}

Tabel 6. Pekerjaan

\begin{tabular}{lcc}
\hline Pekerjaan & Frekuensi & $\begin{array}{c}\text { Persentase } \\
(\%)\end{array}$ \\
\hline Pelajar/Mahasiswa & 21 & $21 \%$ \\
\hline Wiraswasta & 20 & $20 \%$ \\
\hline Karyawan & 38 & $38 \%$ \\
\hline Ibu Rumah Tangga & 16 & $16 \%$ \\
\hline Lainnya & 5 & $5 \%$ \\
\hline Total & 100 & 100 \\
\hline
\end{tabular}

Berdasarkan tabel 6, dapat dilihat bahwa dari 100 responden yang ada, responden yang berstatus pelajar/mahasiswa memiliki persentase sebesar 21\% atau sebanyak 21 responden. Untuk responden dengan pekerjaan wiraswasta mempunyai persentase sebesar $20 \%$ atau sebanyak 20 responden. Untuk responden dengan pekerjaan sebagai karyawan memiliki persentase yang cukup tinggi di bandingkan dengan jenis pekerjaan lainnya sebesar 38\% atau sebanyak 38 responden. Responden dengan pekerjaan sebagai ibu rumah tangga memiliki persentase sebesar $16 \%$ atau sebanyak 16 responden. Sedangkan responden dengan pekerjaan lainnya mempunyai persentase $5 \%$ atau sebanyak 5 responden. Dari data diatas dapat disimpulkan bahwa persentase yang paling tinggi untuk tingkat pekerjaan terdapat pada pekerjaan karyawan.

Maka dari informasi yang telah dikumpulkan dapat dikatakan bahwa dalam penelitian ini responden dengan pekerjaan karyawan yang lebih banyak menggunakan aplikasi ojek online guna memudahkan aktifitas bekerja mereka.

\section{B. Uji Kualitas Data}

Untuk menguji kualitas data penelitian, maka akan dilakukan uji validitas untuk melihat kesesuaian butir pertanyaan kuesioner dan uji 
reliabilitas untuk menguji tingkat kepercayaan dari butir pertanyaan kuesioner agar dapat dihandalkan.

\section{Uji Validitas Data}

Sampel sebesar 100 responden maka df (degree of freedom) $=\mathrm{n}-2$ adalah sebesar 98 dengan tingkat signifikan 5\%, maka diperoleh $\mathrm{r}$ tabel yaitu 0,1966. Pada tabel 7, menjelaskan bahwa dari pengujian validitas yang telah dilakukan untuk variabel kemudahan persepsian, kemanfaatan persepsian dan penerimaan sistem dengan total pernyataan/pertanyaan sebanyak 15 butir. Dari 15 butir yang ada, 6 butir pernyataan untuk variabel kemudahan persepsian, 6 butir pernyataan untuk variabel kemanfaatan persepsian, 3 butir pernyataan untuk variabel penerimaan sistem. Hasil pengujian adalah diperoleh data yang valid adalah sebanyak 15 pernyataan. Dari 15 butir pernyataan yang ada, maka dapat dibuktikan dengan membandingkan $r$ hitung dan $r$ tabelnya, karena semuanya $>0,1966$ maka semua data yang telah diuji dinyatakan valid, sehingga dapat dilanjutkan ke proses pengolahan data selanjutnya.

Tabel 7. Uji Validitas Data 100 Responden

\begin{tabular}{lllll}
\hline Variabel & Item & r hitung & r tabel & Keterangan \\
\hline Kemudahan & KP1 & 0,384 & 0,1966 & Valid \\
\cline { 2 - 5 } Persepsian & KP2 & 0,631 & 0,1966 & Valid \\
\cline { 2 - 5 } & KP3 & 0,750 & 0,1966 & Valid \\
\cline { 2 - 5 } & KP4 & 0,643 & 0,1966 & Valid \\
\cline { 2 - 5 } & KP5 & 0,719 & 0.1966 & Valid \\
\cline { 2 - 5 } Kemanfaatan & KP6 & 0,834 & 0,1966 & Valid \\
\cline { 2 - 5 } Persepsian & KEP1 & 0,793 & 0,1966 & Valid \\
\cline { 2 - 5 } & KEP3 & 0,719 & 0,1966 & Valid \\
\cline { 2 - 5 } & KEP4 & 0,841 & 0,1966 & Valid \\
\cline { 2 - 5 } & KEP5 & 0,806 & 0.1966 & Valid \\
\cline { 2 - 5 } & KEP6 & 0,672 & 0,1966 & Valid \\
\hline Sistem & PS1 & 0,735 &, 1966 & Valid \\
\cline { 2 - 5 } & PS2 & 0,767 & 0,1966 & Valid \\
\cline { 2 - 5 } & PS3 & 0,816 & 0,1966 & Valid \\
\hline
\end{tabular}

\section{Uji Reliabilitas}

Dalam penelitian ini menggunakan analisis cronbach's alpha..

Tabel 8. Uji Reliabilitas Data 100 Responden

\begin{tabular}{lcccc}
\hline Variabel & $\begin{array}{c}\text { Cronbach's } \\
\text { Alpha }\end{array}$ & $\begin{array}{c}\text { Nilai } \\
\text { Alpha } \\
\text { Minimal }\end{array}$ & $\begin{array}{c}\text { N of } \\
\text { Items }\end{array}$ & Keterangan \\
\hline $\begin{array}{l}\text { Kemudahan } \\
\text { Persepsian }\end{array}$ & 0,830 & 0,600 & 6 & Reliabel \\
\hline $\begin{array}{l}\text { Kemanfaatan } \\
\text { Persepsian }\end{array}$ & 0,863 & 0,600 & 6 & Reliabel \\
\hline $\begin{array}{l}\text { Penerimaan } \\
\text { Sistem }\end{array}$ & 0,660 & 0,600 & 3 & Reliabel \\
\hline
\end{tabular}

Suatu kuesioner dapat dinyatakan reliabel apabila nilai Cronbach's Alpha memiliki hasil yang positif. $\mathrm{N}$ of items (number of items) artinya adalah jumlah pertanyaan kuesioner yang peneliti lakukan yaitu totalnya berjumlah 21 butir pertanyaan yang mencakup 3 variabel yaitu kemudahan persepsian, kemanfaatan persepsian dan penerimaan sistem. Dari informasi yang tersedia pada tabel 8, maka dapat diketahui bahwa nilai Cronbach's Alpha untuk variabel kemudahan persepsian adalah 0,830 dengan 6 butir pertanyaan, nilai Cronbach's Alpha untuk variabel kemanfaatan persepsian adalah 0,863 dengan 6 butir pertanyaan, nilai Cronbach's Alpha untuk variabel penerimaan sistem adalah 0,660 dengan 3 butir pertanyaan. Dengan demikian, dapat simpulkan bahwa butir pertanyaan/pernyataan kuesioner ini realiabel karena semua butirnya lebih besar dari 0,1654 atau Cronbach's Alpha memiliki hasil yang positif dan semua variabel memiliki alpha $>0,600$. Ini berarti data hasil kuesioner dapat dipercaya.

\section{Uji Asumsi Klasik}

Penelitian ini akan menggunakan uji normalitas, uji multikolinieritas dan uji heteroskedastisitas dalam melakukan pengujian asumsi klasik.

\section{a. Uji Normalitas}

Penelitian ini menggunakan uji KolmogorovSmirnov Z untuk menguji normalitas data variabel dengan bantuan software SPSS 23. Berikut hasil uji normalitas yang telah peneliti lakukan :

Tabel 9. Uji Normalitas Data

\begin{tabular}{ll}
\hline Asymp. Sig. (2-tailed) & $\begin{array}{l}\text { Kolmogorov-Smirnov } \\
\text { Test }\end{array}$ \\
\hline 0,054 & 0,050 \\
\hline
\end{tabular}

Berdasarkan tabel 9, hasil pengujian normalitas data variabel terikat dan variabel bebas keduanya dinyatakan memiliki data berdistribusi normal karena angka signifikasinya yaitu 0,054 lebih besar dari nilai signifikasi (a) yaitu 0,050.

\section{b. Uji Multikolinieritas}

Uji multikolinieritas bertujuan untuk menguji apakah model regresi ditemukan adanya korelasi antar variabel bebas (independent). Pengujian multikolinieritas dilakukan dengan melihat nilai dari Variance Inflation Factor (VIF) lebih kecil dari 10 dan nilai Tolerancenya lebih besar dari 0,10 . Hal ini berarti tidak terjadi multikolinieritas dalam model regresi.

Tabel 10. Uji Multikolinieritas 


\begin{tabular}{lcc}
\hline \multirow{2}{*}{ Variabel } & \multicolumn{2}{c}{ Collinearity Statistic } \\
\cline { 2 - 3 } & Tolerance & VIP \\
\hline Kemudahan Persepsian & 0,254 & 3,824 \\
\hline Kemanfaatan Persepsian & 0,454 & 1,328 \\
\hline
\end{tabular}

Berdasarkan tabel 10, menunjukkan bahwa variabel kemudahan persepsian memiliki nilai VIF sebesar 3,824 dan lebih kecil dari 10 dan nilai tolerancenya 0,254 yang lebih besar dari 0,10 artinya variabel kemudahan persepsian tidak terjadi multikolinieritas. Pada variabel kemanfaatan persepsian nilai VIF sebesar 1,328 lebih kecil dari 10 dan nilai tolerancenya sebesar 0,454 lebih besar dari 0,10 yang berarti variabel kemanfaatan persepsian tidak terjadi multikolinieritas.

\section{Uji Heteroskedastisitas}

Berikut hasil pengujian

heteroskedastisitas yang telah peneliti lakukan :

Tabel 11. Uji Heteroskedastisitas

\begin{tabular}{ll}
\hline Variabel & Sig. \\
\hline Kemudahan Persepsian & 0,291 \\
\hline Kemanfaatan Persepsian & 0,676 \\
\hline
\end{tabular}

Berdasarkan tabel 11, diketahui bahwa nilai signifikasi kemudahan persepsian sebesar 0,291 lebih besar dari 0,05 artinya tidak terjadi heteroskedastisitas pada variabel kemudahan persepsian. Variabel kemanfaatan persepsian diketahui nilai signifikasinya adalah 0,676 lebih besar dari 0,05 yang artinya tidak terjadi heteroskedastisitas.

\section{Analisis Regresi Linier Berganda}

Tabel 12. Uji Regresi Linier Berganda

\begin{tabular}{lccc}
\hline \multicolumn{1}{c}{ Variabel } & B & T & Sig. \\
\hline Constant & 9,786 & 8,314 & 0,000 \\
\hline $\begin{array}{l}\text { Kemudahan } \\
\text { Persepsi }\end{array}$ & 0,263 & 3,024 & 0,003 \\
\hline $\begin{array}{l}\text { Kemanfaatan } \\
\text { Persepsi }\end{array}$ & 0,108 & 1,495 & 0,033 \\
\hline
\end{tabular}

Model persamaan regresi yang dapat dituliskan dari hasil tersebut dalam bentuk:

$\mathrm{Y}=\mathrm{a}+\mathrm{b} 1 \mathrm{X} 1+\mathrm{b} 2 \mathrm{X} 2+\mathrm{e}$

$\mathrm{Y}=9,786+0,263 \mathrm{X} 1+0,108 \mathrm{X} 2+\mathrm{e}$

Persamaan regresi tersebut dapat dijelaskan sebagai berikut :

a) Konstanta positif sebesar 9,786 memiliki arti bahwa penerimaan sistem akan bertambah sebesar 9,786 jika variabel kemudahan persepsian dan kemanfaatan persepsian adalah konstan.

b) Koefisien regresi variabel kemudahan persepsian yang positif sebesar 0,263 menyatakan bahwa setiap adanya penambahan konstanta sebesar 1 maka akan menambah kepuasan pelanggan sebesar 0,263 .

c) Koefisien regresi variabel kemanfaatan persepsian yang positif sebesar 0,108 menyatakan bahwa setiap adanya penambahan konstanta sebesar 1 maka akan menambah kepuasan pelanggan sebesar 0,108 .

\section{Uji Hipotesis}

1. Uji Statistika T

Hasil pengujian nilai $t$ digunakan untuk mengetahui apakah secara parsial kemudahan persepsian dan kemanfaatan persepsian berpengaruh secara signifikan atau tidak terhadap variabel penerimaan sistem.

a. Pada tabel 12 untuk variabel kemudahan persepsian menunjukkan nilai $\mathrm{t}=3,024$ dengan nilai signifikansi 0,003 $<0,05$. Dengan demikian diambil kesimpulan bahwa variabel kemudahan persepsian memiliki pengaruh yang signifikan terhadap penerimaan aplikasi ojek online di Indonesia dengan sistem TAM (Technology Acceptance Model)

b. Pada tabel 12 untuk variabel kemanfaatan persepsian menunjukkan nilai $\mathrm{t}=1,495$ dengan nilai signifikansi 0,033 $<0,05$. Dengan demikian diambil kesimpulan bahwa variabel kemanfaatan persepsian memiliki pengaruh yang signifikan terhadap penerimaan aplikasi ojek online di Indonesia dengan sistem TAM (Technology Acceptance Model)

\section{Uji Statistika F}

Berdasarkan tabel 13, diperoleh hasil uji $\mathrm{F}$ yang berfungsi untuk mengetahui bagaimanakah pengaruh semua variabel independen terhadap variabel dependen secara bersamaan. Berdasarkan hasil tabel diperoleh Fhitung sebesar 3,080 dengan tingkat signifikansi 0,005 dibawah dari nilai signifikansi 0,05. Maka dapat dikatakan model regresi dapat dipakai untuk memprediksi variabel penerimaan sistem sebagai variabel dependen dipengaruhi oleh kemudahan persepsian dan kemanfaatan persepsian secara bersamaan.

Tabel 13. Uji F

\begin{tabular}{ccccc}
\hline Model & & Df & F & Signifikansi \\
\hline 1 & Regression & 2 & $\mathbf{3 , 0 8 0}$ & $\mathbf{0 , 0 0 5}$ \\
\hline
\end{tabular}




\begin{tabular}{ll}
\hline Residual & 97 \\
\hline Total & 99 \\
\hline
\end{tabular}

Maka rumusan hipotesis penelitian ini adalah :

Ho : Tidak terdapat pengaruh secara signifikan antara kemudahan persepsian dan kemanfaatan persepsian secara bersama-sama terhadap penerimaan sistem TAM (Technology Acceptance Model).

H1 : Terdapat pengaruh secara signifikan antara kemudahan persepsian dan kemanfaatan persepsian secara bersama-sama terhadap penerimaan sistem TAM (Technology Acceptance Model)

\section{Koefisien Determinasi}

Berdasarkan tabel 14, diperoleh koefisien korelasi sebesar 0,409 yang artinya terdapat pengaruh yang kuat antara kemudahan persepsian dan kemanfaatan persepsian terdahap penerimaan sistem aplikasi ojek online. Nilai Adjusted R Square yang diperoleh sebesar $0,142 \quad(14,2 \%)$ menunjukkan bahwa variabel penerimaan sistem dipengaruhi oleh variabel kemudahan persepsian dan kemanfaatan persepsian sebesar 14,2\%, sedangkan sisanya $85,8 \%$ dipengaruhi oleh variabel lain diluar penelitian ini.

Tabel 14. Koefisien Determinasi

\begin{tabular}{ll}
\hline $\mathrm{R}$ & Adjusted R Square \\
\hline 0,409 & 0,142 \\
\hline
\end{tabular}

\section{Pembahasan}

\section{Kemudahan Persepsian Terhadap Penerimaan Sistem}

Pengujian yang telah dilakukan pada regresi berganda dengan menggunakan uji t menunjukkan kemudahan persepsian berpengaruh secara positif dan signifikan terhadap penerimaan sistem. Hal ini ditunjukkan dengan nilai $\mathrm{t}=3,024$ dengan nilai signifikansi 0,003 yang lebih kecil dari 0,05, dengan demikian hipotesis pertama diterima. Nilai positif dapat diartikan bahwa apabila pengaruh kemudahan meningkat maka penerimaan sistem aplikasi ojek online juga akan meningkat. Hal ini juga mendukung keenam indikator kemudahan persepsian menurut Fatmawati (2015) yaitu, indikator pertama dengan memiliki tingkat rhitung sebesar 0,384 dimana lebih besar dari rtabel, indikator kedua dengan tingkat rhitung sebesar 0,631, indikator ketiga dengan rhitung sebesar 0,750, indikator keempat sebesar 0,643, indikator kelima dengan rhitung sebesar 0,719 dan indikator keenam sebesar 0,834 dinyatakan valid. Pada pengujian reliabilitas dengan menggunakan analisis cronbach's alpha menunjukkan bahwa variabel kemudahan persepsian bernilai positif sebesar 0,830 dengan 6 butir pernyataan yang dapat dipercaya. Pada pengujian asumsi klasik dengan menggunakan uji normalitas, uji multikolinieritas dan uji heteroskedastisitas. Nilai variabel kemudahan persepsian dengan pengujian multikolinieritas menunjukkan bahwa nilai Tolerance 0,254 dimana lebih besar dari 0,10 serta nilai Variance Inflation Factor (VIF) 3,824 dimana lebih kecil dari 10 dengan ini variabel kemudahan persepsian tidak menunjukkan adanya multikolinieritas. Variabel kemudahan persepsian juga menunjukkan bahwa tidak terjadinya heteroskedastisitas dimana nilai signifikasi sebesar 0,291 lebih besar dari 0,05.

\section{Kemanfaatan Persepsian Terhadap Penerimaan Sistem}

Pengujian yang telah dilakukan pada variabel kemanfaatan persepsian menunjukkan bahwa keenam indikator dinyatakan valid dan dapat dilanjutkan pada pengujian selanjutnya (Fatmawati, 2015). Terlihat pada uji validitas data dimana indikator pertama sebesar 0,793, indikator kedua sebesar 0,719, indikator ketiga sebesar 0,811, indikator keempat sebesar 0,841, indikator kelima sebesar 0,806 dan indikator keenam sebesar 0,672 masing-masing indikator menunjukkan bahwa nilai rhitung lebih besar dari 0,1966 yang merupakan nilai rtabel. Pada uji reliabilitas data nilai pada variabel kemanfaatan persepsian sebesar 0,863 dimana nilai alpha minimal 0,600. Keenam indikator kemanfaatan persepsian dinyatakan reliabel atau dapat dipercaya karena nilai cronbach's alpha yang bernilai positif dan lebih besar dari rtabel. Pada pengujian asumsi klasik didapat nilai tolerance untuk uji multikolinieritas sebesar 0,454 serta nilai Variance Inflation Factor (VIF) sebesar 1,328 dengan ini menunjukkan bahwa tidak terjadinya multikolinieritas pada variabel kemanfaatan persepsian. Pada pengujian heteroskedastisitas menunjukkan bahwa nilai pada variabel kemanfaatan persepsian sebesar 0,676 lebih besar dari nilai 0.05. Dari hasil uji $t$ menyatakan bahwa variabel kemanfaatan persepsian memiliki pengaruh secara signifikan terhadap penerimaan sistem berdasarkan hasil output spss yang menunjukan bahwa thitung 1,495 lebih besar dari ttabel 1,661 dan signifikasi dibawah dari 0,05 yaitu sebesar 0,000.

Sementara pada hasil perhitungan koefisien determinasi dapat disimpulkan bahwa variabel independen dalam penelitian ini mampu menerangkan nilai Adjusted $\mathrm{R}$ Square yang diperoleh sebesar 0,142 (14,2\%) menunjukkan bahwa variabel penerimaan sistem dipengaruhi 
oleh variabel kemudahan persepsian dan kemanfaatan persepsian sebesar 14,2\%, sedangkan sisanya $85,8 \%$ dipengaruhi oleh variabel lain diluar penelitian ini.

Berdasarkan uji $\mathrm{F}$ hasil tabel diperoleh Fhitung sebesar 3,080 dengan tingkat signifikansi 0,005 dibawah dari nilai signifikansi 0,05 . Maka dapat dikatakan model regresi dapat dipakai untuk memprediksi variabel penerimaan sistem sebagai variabel dependen dipengaruhi oleh kemudahan persepsian dan kemanfaatan persepsian secara bersamaan.

\section{REFERENSI}

Fahmi, M., Umyati, U., Riyanto, B., \& Basuki, K. H. (2015). PEMODELAN PEMILIHAN MODA DENGAN METODE STATED PREFERENCE, STUDI KASUS PERPINDAHAN DARI SEPEDA MOTOR KE BRT RUTE SEMARANG KENDAL. JURNAL KARYA TEKNIK SIPIL, 4(4), 343-352. Retrieved from https://ejournal3.undip.ac.id/index.php/jkts /article/view/10318

Fatmawati, E. (2015). Technology Acceptance model (TAM) untuk menganalisis penerimaan terhadap sistem informasi di perpustakaanM INFORMASI PERPUSTAKAAN. IQRA': JURNAL PERPUSTAKAAN DAN INFORMASI, 9(1), 1-13. https://doi.org/10.30829/IQRA.V9I1.66

Rachman, T. (2015). Kerugian Akibat Macet di Jakarta Capai Rp 65 Triliun per Tahun | Republika Online. Retrieved August 13, 2017, from

https://www.republika.co.id/berita/nasiona l/jabodetabeknasional/15/05/22/noqqrokerugian-akibat-macet-di-jakarta-capai-rp65-triliun-pertahun

Sengkey, S. L., Jansen, F., \& Wallah, S. E. (2011). TINGKAT PENCEMARAN UDARA CO AKIBAT LALU LINTAS DENGAN MODEL PREDIKSI POLUSI UDARA SKALA MIKRO. JURNAL ILMIAH MEDIA ENGINEERING, 1(2). Retrieved from https://ejournal.unsrat.ac.id/index.php/jime /article/view/4218

Soebali, L. F., \& Mahendra, I. (2017). ANALISA FAKTOR-FAKTOR YANG MEMPENGARUHI PENERIMAAN DAN PENGGUNAAN APLIKASI GO-JEK MENGGUNAKAN UNIFIED THEORY OF ACCEPTANCE AND USE OF TECHNOLOGY (UTAUT). Jurnal Pilar Nusa Mandiri, 13(1), 136-144.
https://doi.org/10.33480/PILAR.V13I1.348

Soesilowati, E. (2008). DAMPAK PERTUMBUHAN EKONOMI KOTA SEMARANG TERHADAP KEMACETAN LALULINTAS DI WILAYAH PINGGIRAN DAN KEBIJAKAN YANG DITEMPUHNYA. JEJAK: Jurnal Ekonomi Dan Kebijakan, $1(1)$. https://doi.org/10.15294/JEJAK.V1I1.1447

Sugiyono. (2010). Metode Penelitian Bisnis. Bandung: Alfabeta.

Zuraya, N. (2016). Dishub: Kemacetan di DKI Jakarta Sebabkan Kerugian Rp 150 Triliun. Retrieved March 1, 2017, from https://www.republika.co.id/berita/nasiona l/jabodetabeknasional/16/04/25/o66jqo383-dishubkemacetan-di-dki-jakarta-sebabkankerugian-rp-150-triliun 